低発塵性コーティング技術

清原 正勝*1 · 鳩野 広典*2 ·岩澤 順一*1

\title{
A New Plasma Resistant Coating Reducing Particle Generations
}

\author{
Masakatsu KIYOHARA*1, Hironori HATONO*2 and Junichi IWASAWA*1 \\ ${ }^{* 1}$ Advanced Ceramics Engineering, Advanced Ceramics Div. TOTO LTD, 10, Tajirizaki, Nakatsu-City OITA-Pref, 879-0124, Japan \\ *2Material Research Dept., Research Institute, TOTO LTD, 2-8-1, Honson Chigasaki-City KANAGAWA-Pref, 253-8577 Japan
}

(Received March 13, 2010, Accepted July 14, 2010)

\begin{abstract}
Aerosol Deposition Method (ADM) is a new technology of ceramics film deposition. Using this method, we can deposit various ceramics thick films (one-several hundreds micrometer of thickness) on metal, glass and ceramics substrates. It's normal temperature process and doesn't require any heating expedient. Films have dense nano-crystalline structure, good adhesion on many substrate and good mechanical properties. For several years we have been developing this process. In this paper, overview of application to semiconductor manufacturing equipment parts by ADM was reported.
\end{abstract}

\section{1. はじめに}

トランジスタが発見されてから50年以上が経過し，半導 体産業の歴史も半世紀に及んでいる。この間の技術進歩はめ ざましく, IC から LSI, 超 LSIへと, 高密度化, 高集積化 が次々と達成されてきた。半導体産業といえばすべての産業 の中で, 最も先端的な製造技術によって製品を生久出す分野 であり，それを生み出しているのが半導体製造装置である11.

半導体製造装置は, 半導体デバイスを製造するために必要 な「装置」であり，言い換えると「ッール（道具）」である. このツールが最先端でなければ, 最先端のデバイスを生み出 すこともできない.

近年の半導体デバイス製造においては, 微細加工技術の進 歩と基板の大口径化技術開発により，デバイスの高集積化と 低コスト化が推し進められている。この中で, 装置構成部材 から発生するコンタミネーションが, デバイス性能を劣化さ せ, 寿命の短い部品は生産性を低下させデバイスの低コスト 化の妨げになる，このことから装置構成部材においては, 高 純度化・長寿命化等の向上が求められている.

Table 1 に, 半導体製造装置に応用されている代表的なセ
ラミック材料ををとめた ${ }^{2}$.

これらの用途を見てみると, セラミックスの持つ軽い・硬 い.強いといった機械的物性の応用だけではなく, プラズマ 耐食性やメタルコンタミフリーといったデバイス特性や生産 歩留まりの確保を目的とした用途も多い.このような用途で は, 装置メーカー及び材料供給メーカーが共に開発を進め, 日々改善を行っているのが現状である.

また，これら装置に抢けるセラミックスの使用形態として は，ほとんどがセラミックス焼成体での使用であったが，溶 射法に代表されるようなコーティング技術も, 部分的に耐食 性，絶縁性を付与する用途に応用されて来ている.

ただ, 溶射法 ${ }^{3-5)}$ は, 粉体を加熱し半溶融状態で基材上に 製膜することから，製膜される基材は耐熱性を加味した材料 や部材設計が必要であり, 製造装置内のすべての構成部材 · 部位への展開は難しい.

本稿で紹介するエアロゾルデポジション法（AD 法）は， 熱プロセスを必要としないことから，製膜される基材はセラ ミック・ガラス・金属及び一部高分子材料など多くの材料へ 直接コーティングできるといった汎用性の高い製膜方法であ る. 製膜された製膜体は, 加熱工程を経ていないことから製

Table 1 Typical ceramic materials applied to semiconductor manufacturing equipment.

\begin{tabular}{c|c|c|l}
\hline $\begin{array}{c}\text { Semiconductor manufac- } \\
\text { turing equipument }\end{array}$ & Component & Material & \multicolumn{1}{c}{ Reason for application } \\
\hline All & Carrier arm & $\mathrm{Al}_{2} \mathrm{O}_{3}$ & Stiffness, Machining accuracy, Cost reducution \\
\hline CVD & Stage heater & $\mathrm{AlN}, \mathrm{SiC}$ & Thermal property, Corrosion resistance \\
\hline Wafer prober & Wafer stage & $\mathrm{Al}_{2} \mathrm{O}_{3}$ & Flatness, Stiffness \\
\hline Etcher & Wafer stage (ESC) & $\mathrm{Al}_{2} \mathrm{O}_{3}$ & Electrical property \\
\hline All & Wafer Lifter & $\mathrm{Al}_{2} \mathrm{O}_{3}$ & $\begin{array}{l}\text { Machining accuracy, Corrosion resistance, Metal contamination, } \\
\text { Cost reduction }\end{array}$ \\
\hline Etcher & Chamber materials & $\mathrm{Al}_{2} \mathrm{O}_{3}, \mathrm{Y}_{2} \mathrm{O}_{3}$ & Plasma erosion resistance, Low particle property \\
\hline
\end{tabular}

*1 TOTO侏セラミック事業部セラミック技術部（元879-0124 大 分県中津市田尻崎10)

*2 TOTO秼総合研究所素材研究部 ( $=253-8577$ 神奈川県茅ケ崎 市本村 2-8-1) 
膜体中の粒子は加熱による粒成長も無くナノオーダーの組織 から構成される. また, ポアを含をない透明な緻密な膜質で あり，製膜体厚みは，製膜するセラミックスや製膜される基 材の材質によるが数〜数百 $\mu \mathrm{m}$ の製膜体を得ることができ る.このように $\mathrm{AD}$ 法は非加熱プロセスによりナノオー ダーの緻密な組織を実現する新しいセラミックコーティング 技術である。

一方, 半導体製造では, 電子デバイスの高性能化を図るた めにナノメーター・オーダーでの微細なパターン幅での配線 加工が要求される．基板上に付着するパーティクルは製品不 良に直結するので, 装置材料から発生する粒子の大きさ・脱 落量を如何に抑制するかが重要となって来ている.

本技術は, 半導体をはじめとする各種デバイス製造装置に おいてパーティクルを減少させるためのコーティング技術と して期待されている.

本解説では, まず, この $\mathrm{AD}$ 法の概要を紹介し, 現在半 導体装置に多く使用されている溶射法で作製した膜との性能 比較評価を行った. 更に, 実際に半導体製造装置の環境下で の試験を通し，パーティクル抑制効果の有効性について検証 したので以下に述べる.

\section{2. エアロゾルデポジション法}

\section{1 製膜現象と製膜装置}

エアロゾルデポジション法（AD 法）とは，セラミックス の微粒子をガス中に分散させたエアロゾル（ガス中に粉体が 浮遊した状態）をノズルから高速で, 基材に向けて噴射して 衝突させることで, 基材上にそのセラミックスの膜を形成す る技術である. 製膜の概略図を Fig. 1 に示す. 微粒子の噴 射衝突を利用する方法としては, 前述の溶射法が有名であ る.一見溶射法に似ているように想えるが，大きく異なる点 は, 溶射法はノズル付近でアセチレンや酸素ガスを用いて加 熱して粉体を溶融状態で噴射させるのに対して, $\mathrm{AD}$ 法は加 熱手段を用いずに粉体を固体状態で噴射する完全な常温での 製膜技術であることである。

さらに， $\mathrm{AD}$ 法に用いる粉体はサブミクロン領域の粒径を 有する微粒子が用いられ, 微粒子の衝突速度は $400 \mathrm{~m} / \mathrm{s}$ 以下 と溶射法に比べ低い状態で製膜が可能であることが特徵であ る. 形成された製膜体は，ポアを含まず，緻密で透光性を有 し, 基材との密着力も高い膜形成ができるという点も特徵と して挙げられる.

Fig. 2 に $\mathrm{AD}$ 法の製膜装置の構成について示す。まず, 製膜フローについて説明する。装置は, 市販の窒素やへリウ

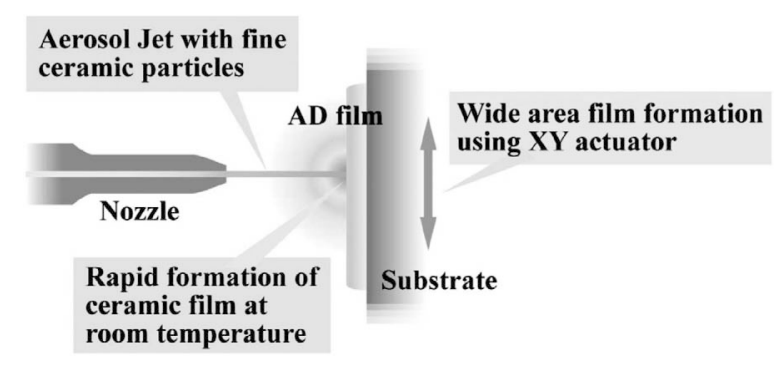

Fig. 1 Film formation process of aerosol deposition (AD).
ムガスを供給する搬送ガス部，製膜したいセラミック微粒子 が搬送ガスと十分に混合・分散したエアロゾルを生成するエ アロゾル発生部，このエアロゾルを基材に向けて搬送し噴射 する搬送管と噴射ノズル，ノズルの前方に設置した基材とか らなっている. 衝突後のガス（エアロゾル）は通常真空ポン プにて外部へ排気させるため, チャンバー内は数十〜数百 $\mathrm{Pa}$ の低真空䨌囲気となる，基材には金属，ガラス，セラミ ックスなどが使用され，一部のプラスチックスにも膜形成が できることが確認されている.

Fig. 3 に，一部に PVD 法で金属パターン（文字）を形成 した $100 \mathrm{~mm}$ 角のガラス基板上に， $\mathrm{AD}$ 法によって約 $20 \mu \mathrm{m}$ のアルミナ膜を形成させたサンプルを示す.

$\mathrm{AD}$ 法は，非常に単純な装置構成によって，単にセラミッ ク微粒子を基材に衝突させるだけであるにも関わらず，緻密 な膜が形成できる興味深い技術と言える.

この技術は1990年代後半に産総研の明渡らのマイクロマ シンに用いるアクチュエータ素子作製の研究に端を発す

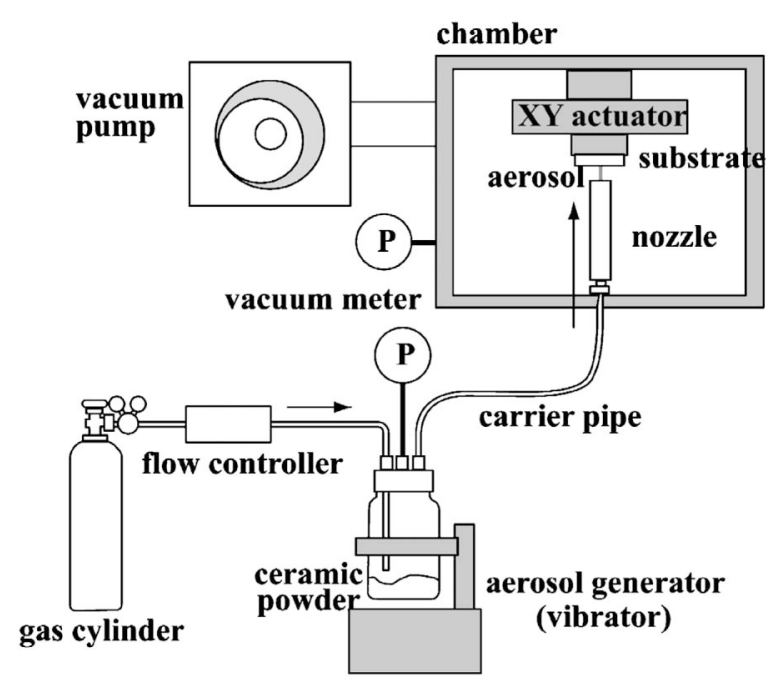

Fig. 2 Aerosol deposition apparatus.

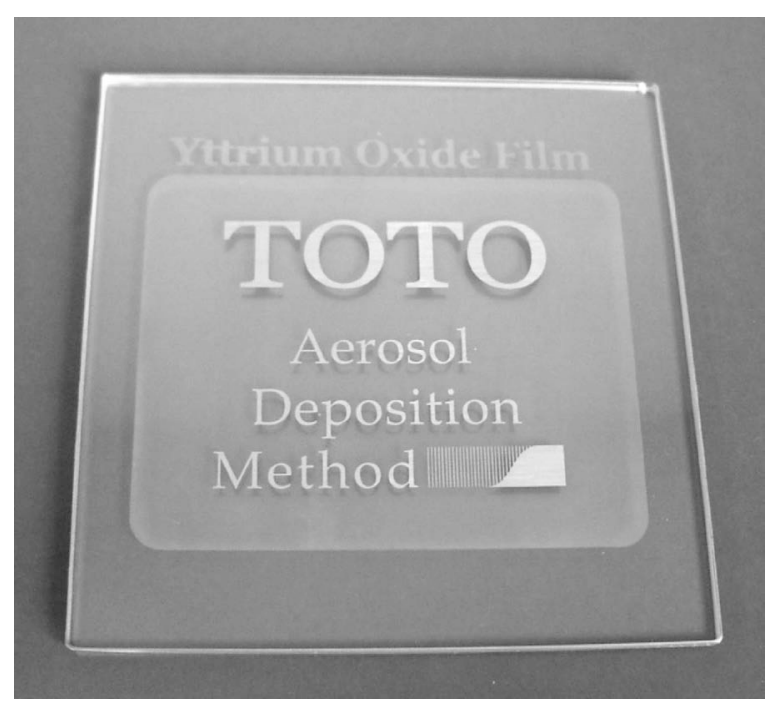

Fig. $3 \quad \mathrm{Al}_{2} \mathrm{O}_{3}$ film on the glass substrate with thin metal logo image. 
る ${ }^{6-8)}$. PZT 圧電セラミックを数百 $\mu \mathrm{m}$ 厚みでシリコン基板 上に形成させることに成功した.

\section{2 製膜体の特徵について}

Fig. 4 に，シリコンウェハ基板上に AD 法で形成したア ルミナ膜断面 TEM 写真を示す。膜を構成する粒子の結晶子 サイズは百 $\mathrm{nm}$ 以下であり, 製膜に用いた原料微粉体の結晶 子サイズよりも小さくなっていた。 また，粒子間の界面には 隙間が無くはっきりとした粒界層の確認もできなかった。こ れは，熱プロセスを介した溶射や焼成法で作製された組織と は異なるものである.

シリコンウェ八基板と製膜体の界面を観察すると, 基板に セラミックス粒子が突き刺さっている状態が観察される.つ まり，本製膜体は基材にアンカー部を形成し製膜体を作って おり，製膜体と基材との密着力は大きいことが予測できる.

Table 2 に, AD 法にて形成した膜と, 装置部材として実 用化されている高純度の焼成体抢よび溶射法で作製された膜 との比較結果を示す。具体的には, アルミ合金上に, $\mathrm{AD}$ 法, 溶射法で製膜した二種類の製膜体と高純度アルミナ（純 度99.9\%）焼成体について, 絶縁耐圧ならびに各種機械的特 性を示した． AD 法での製膜体は，マイクロビッカースで測 定した膜硬度の結果から，バルク焼成体並とはいかないもの の, 製膜条件によっては減圧プラズマで作製した溶射膜以上 の硬度を有していることがわかった. さらに, 膜と基材の密 着力を引き倒し法9,10)にて評価した結果, $\mathrm{AD}$ 法にて作製さ れた膜は, 溶射法の $20 \mathrm{MPa}$ に比べ, $70 \mathrm{MPa}$ 以上と高い密 着力を得られることが明らかになった.

耐電圧試験結果においても， $\mathrm{AD}$ 法で作製した膜の耐電圧 は, $1 \mu \mathrm{m}$ 厚さ当たり $150 \mathrm{~V}$ 以上と溶射法 ·焼成体に比べて 1 桁以上高い值を示すことがわかった。

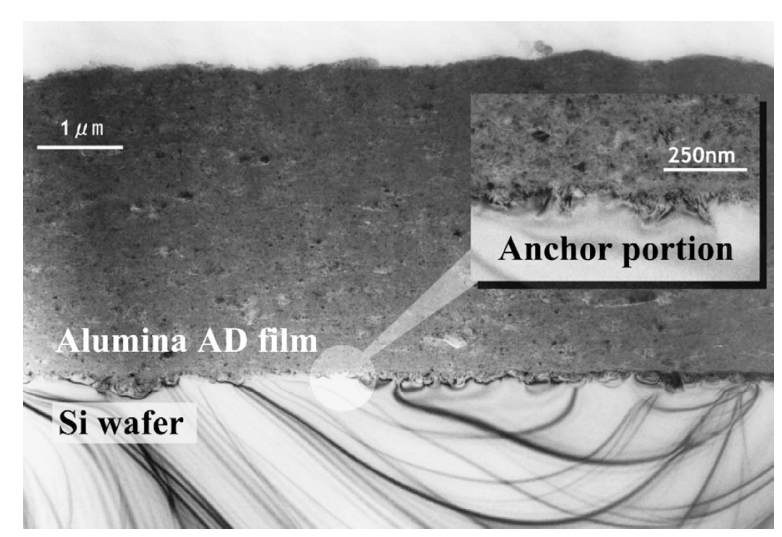

Fig. 4 Cross sectional TEM image of $\mathrm{Al}_{2} \mathrm{O}_{3}$ film.
これらの優れた膜の特性は, 形成粒子のアンカー効果や, ポアの少ない緻密な膜質によるものである.

\section{3. 半導体製造装置用部材への応用について}

\section{1 半導体製造装置における課題}

以上述べてきたように, $\mathrm{AD}$ 法は, 常温製膜可能であるた め基材の選択性が高く緻密で基材への密着力の大きな膜が得 られるという優れた特徵をもっている.このことから, 応用 範囲が広がるものと考えられる。

特に 結晶子が小さく緻密な膜を形成できることから， パーティクルの発生を嫌う半導体製造装置部材への適用が期 待できる。

具体的な例として, ドライエッチング装置では, 塩素系, フッ素系, 臭素系のガスなど腐食性が強いガスのプラズマを 利用する. 当然装置内の材料には, プラズマ耐食性が要求さ れるのであるが, ある一定期間使用するとプラズマによる侵 食を受けてパーティクルの発生が避けられないのが実情であ る. 装置内部材のプラズマ耐食性を向上させ, パーティクル の発生を抑制できれば，パーティクルによる不良を低減でき るとともに, 部品交換頻度の削減にもなり生産性の向上とコ スト低減を同時に図ることができる.

ドライエッチング装置内の材料としては，メタルコンタミ ネーション防止の観点から石英ガラスが多く用いられ, さら にプラズマ耐食性を向上させる目的で, 石英ガラス上にサフ アイアコートを施す工夫も試みられてきた. 最近になって特 にフッ素ガスプラズマに耐食性がある材料として, 窒化アル ミニウム $(\mathrm{AlN})$ やイットリア（酸化イットリウム： $\mathrm{Y}_{2} \mathrm{O}_{3}$ ) が注目されるようになり, 焼結体部品がドライエッチング装 置内の部材として検討され始めている11).

しかし，イットリアは焼成温度が高く $\left(1600 \sim 1800^{\circ} \mathrm{C}\right)$, 焼成時の雾囲気制御も難しいために, アルミナ等の一般的な 構造用セラミックと比較して高価となる. さらに抗折強度が アルミナの約半分程度と, 強度的にも問題があることから, 装置内部材への適用が制限されているのが実情である.

そこで, 機械的強度が大きい比較的安価な部材の表面にプ ラズマ耐食性を持つセラミックスをコーティングする技術が 注目され始めた．特に溶射法によるイットリアコーティング が盛んに検討されている12,13).

\section{$3.2 \mathrm{AD}$ 法によるセラミック膜の耐プラズマ性}

既に述べたように， $\mathrm{AD}$ 法には緻密で基材への密着力が強 い膜を得られるという優れた特徵を持つ. その特徵により, 耐プラズマコーティング膜としての応用が期待できる．本節 では，AD 法により製作したイットリア膜の耐プラズマ性に

Table 2 Electrical and mechanical properties of $\mathrm{Al}_{2} \mathrm{O}_{3}$ films, the sintered bulk.

\begin{tabular}{c|c|c|c|c|c}
\hline \hline & Substrate & $\begin{array}{c}\text { Film thickness } \\
(\mu \mathrm{m})\end{array}$ & $\begin{array}{c}\text { Micro vickers hardness } \\
\mathrm{Hv}\end{array}$ & $\begin{array}{c}\text { Adhesion force } \\
(\mathrm{MPa})\end{array}$ & $\begin{array}{c}\text { Withstanding voltage } \\
(\mathrm{V} / \mu \mathrm{m})\end{array}$ \\
\hline $\mathrm{Al}_{2} \mathrm{O}_{3} \mathrm{AD}$ film & $\mathrm{Al}$ alloy & 10 & $800-1400$ & 70 & $>150$ \\
\hline $\begin{array}{c}\mathrm{Al}_{2} \mathrm{O}_{3} \text { reduced-pressure } \\
\text { plasma spraying film }\end{array}$ & $\mathrm{Al}$ alloy & 110 & 1000 & 20 & 50 \\
\hline Sintered $\mathrm{Al}_{2} \mathrm{O}_{3}$ & - & - & $1600-1800$ & - & 12 \\
\hline
\end{tabular}


ついて述べる.

イットリアの製膜は, 原料純度 $99.9 \%$, 平均粒子径約 0.5 $\mu \mathrm{m}$ 程度の $\mathrm{Y}_{2} \mathrm{O}_{3}$ 微粒子を, エアロゾル化する搬送ガスにへ リウムを用いて作製した。基板には，石英ガラスを用い， $100 \mu \mathrm{m}$ の膜厚で製膜した ${ }^{14-17)}$ 。これにより得られたイット リア膜の硬度は, HIPによるイットリア焼結体の $662 \mathrm{Hv}$ を 上回る $944 \mathrm{Hv}$ と大きな值を示した.

次に，プラズマ耐食性について述べる，評価には，異方性 エッチングに最も広く用いられている平行平板型の反応性イ オンエッチング（RIE : Reactive Ion Etching）装置を用い た. 装置内に試料を設置し, 実際にエッチングを行うことで 試料に損傷を与えた.この際試料の一部をシリコンウェハで 被覆し, プラズマに暴露させない領域を確保した.エッチン グは, 絶縁膜ドライエッチング工程で用いられる四フッ化炭 素々酸素の混合ガス $\left(\mathrm{CF}_{4}+\mathrm{O}_{2}\right)$ を用い, 投入電力 $1 \mathrm{~kW}$ で, $180 \min$ の照射を行った.

エッチング終了後, プラズマに曝された部分とシリコンウ エハで被覆した部分の段差を触針式表面形状測定器により測 定し，その段差を侵食深さとして求めた。 また，試料表面の 走査型電子顕微鏡 (SEM : Scanning Electron Microscope) による拡大観察を行ない, エッチング部と非エッチング部の 表面状態の違いについても評価を行った.

評価は, 高純度アルミナ焼成体 HIP 処理品（純度 99.9 \%)，イットリア焼成体 HIP 処理品（純度 $99.9 \%$ ，，AD 法 で作製したイットリア膜について行なった。なお，高純度ア ルミナ焼成体 HIP 処理品は, 半導体 ·フラットパネルディ スプレイ製造装置に使用実績があるものである.Fig. 5 に 侵食深さの比較結果を, Fig. 6 に SEM 観察結果を示す.

Fig. 5 に示した結果より, $\mathrm{AD}$ 法で作製したイットリア膜 の侵食深さは，イットリア焼成 HIP 品とほぼ同等であり, 高純度アルミナ焼成 HIP 品と比べる $1 / 4$, すなわち約 4 倍 の耐食性を有することがわかる。

また, Fig. 6 に示した SEM 観察結果より，イットリア焼 成 HIP 品ではポアの周囲が顕著に侵食, 脱落した様子が観 察されるが, $\mathrm{AD}$ 法で作製した膜には, 表面状態の变化はほ とんど無く部分的な侵食・脱落が認められなかった．これ は, 表面にポアが存在しない緻密な膜であるためと考えられ る.

これらのことから考察すると, 焼成体はポア部を起点に侵 食・脱落するのに対して, $\mathrm{AD}$ 膜はポアがなく部分的な侵食 はなく, 表面が一様に均一に侵食されるものと推測できる.

以上より, イットリアは耐プラズマ性を有し, さらに $\mathrm{AD}$ 法で作製したイットリア膜は, 表面の部分的な粒子の侵食 · 脱落が無いことがわかった.このことは， $\mathrm{AD}$ 法で作製した イットリア膜は, 部品寿命を長く出来ることはもちろんであ るが, 表面のポアを基点とした粒子脱落も少ないことを示唆 している，つまり，パーティクル発生の少ない膜を提供でき るコーティング技術であると言える.

現在， $\mathrm{AD}$ 法で作製した製膜体は，以上に述べたようなプ ラズマ耐食性と膜の透光性を生かして, 装置内部監視用ガラ ス空の内面コーティングに応用を進めている。具体的には, ビューポート, 終点検知空などへも展開を実施しており, 良

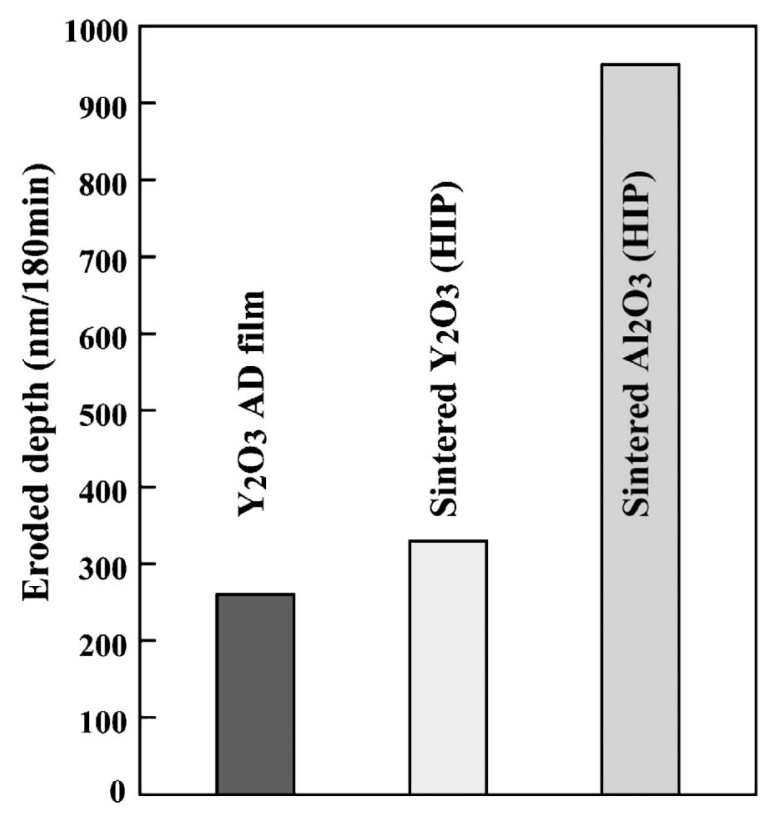

Fig. 5 Change over time of eroded depth of various materials by plasma irradiation.
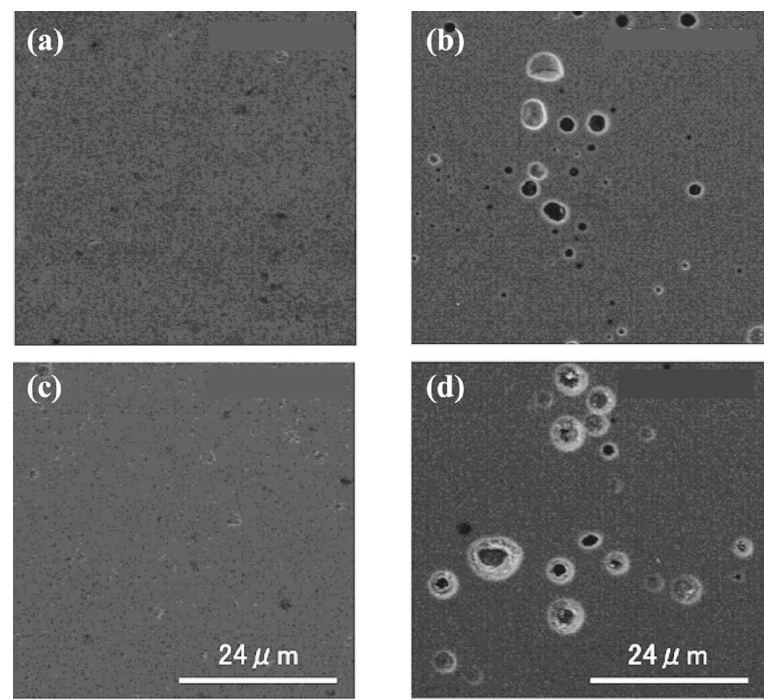

Fig. 6 Change of surface morphology: (a) $\mathrm{Y}_{2} \mathrm{O}_{3} \mathrm{AD}$ film, (b) sintered $\mathrm{Y}_{2} \mathrm{O}_{3}$ bulk (HIP) before plasma irradiation; (c) $\mathrm{Y}_{2} \mathrm{O}_{3}$ AD film, (d) sintered $\mathrm{Y}_{2} \mathrm{O}_{3}$ bulk (HIP) after plasma irradiation.

好な結果が得られている.

\section{4. まと め}

本稿では, エアロゾルデポジション法（AD 法）を紹介し た． $\mathrm{AD}$ 法は，熱プロセスを有さず緻密な製膜体を得ること ができる新しい製膜技術である，さらに $\mathrm{AD}$ 法によるイッ トリア膜は, プラズマ耐食性に優れ, 従来から半導体装置の チャンバー内部材等に用いられている材料と比較して, 優れ たプラズマ耐食性を持つことを示した.

今後, 半導体やフラットパネルディスプレイ製造装置にお いては，低発塵化及び部材の長寿命化のニーズが高まると同 時に, 更なる大型化や複雑な形状へのコーティングの要望が 
出てくるものと予測される.

本技術は, 現在 $600 \mathrm{~mm}$ の基板サイズ, さらには立体形状 の製膜化も可能となっており，更なる用途展開を推進中であ る.

\section{[文献 $]$}

1) K. Maeda: Hajimete no handoutai souti, kougyoutyousakai, Tokyo (1999) $12^{\text {th }}$ ed. p. 10.

2) Y. Kobayashi: Text of 37th Seminar of High-Temperature Ceramics, Osaka, Japan, 2005, 1 (2005) 1-7.

3) T. Itsukaichi: FC Report, 23[1], (2005) 12-17.

4) R. Harada: FC Report, 23[1], (2005) 18-22.

5) Y. Itoh: FC Report, 23[1], (2005) 23-27.

6) J. Akedo et al: Jpn. J. Appl. Phys., 68[1], (1999) 44.
7) J. Akedo et al.: Sensor \& Actuator A-Phys., 69 (1998) 106.

8) J. Akedo et al.: Jpn. J. Appl. Phys., 38, P1-9B, (1999) 5397.

9) D. W. Butler: J. Phys. E. 3 (1970) 970-971.

10) J. M. Burkstrand: J. Vac. Sci. Technol., (1982) 20440-441.

11) M. Nakahara: Text of 38th Seminar on Engineering Ceramics, Osaka, Japan, 2006, (2006) 34-39.

12) J. Iwasawa: Text of 37th Seminar of High-Temperature Ceramics, Osaka, Japan, 2005, 1 (2005) 32-37.

13) J. Iwasawa: Text of 39th Seminar on Engineering Ceramics, Osaka, Japan, 2005, 1 (2006) 42-47.

14) J. Iwasawa et al., J. Am. Ceram. Soc., 90[8] , (2007) 23272332 .

15) J. Iwasawa et al., J. Ceram. Soc. Jpn, 114[3], (2006) 272-276.

16) J. Iwasawa: FC Report, 23[2], (2005) 86-87.

17) J. Iwasawa et al.: Trans. Mater. Res. Soc., Jpn, 30[4], (2005) 1009-1012. 